\title{
赤外分光分析による蓚酸カルシウム結石の定量分析
}

\author{
自治医科大学泌尿器科 \\ （主任：米瀬泰行教授) \\ 森口英 男

\section{QUANTITATIVE ANALYSIS OF CALCIUM OXALATE STONES BY INFRARED SPECTROSCOPY}

\author{
Hideo Moriguchi \\ Department of Urology, Jichi Medical School \\ (Director: Prof. Yasuyuki Yonese, M.D.)
}

Powder samples of 80 upper urinary tract stones composed of weddellite and/or whewellite and apatite, the contents of which had been estimated by thermogravimetry (TG)4), were analysed with two kinds of the double-beam recording infrared spectrophotometers, $620 \mathrm{MX}$ of Beckman Instruments, Inc. and IRA-2 of Japan Spectroscopic Co. Ltd.. A $1.0 \mathrm{mg}$ powder sample was weighed and mixed with $150 \mathrm{mg}$ or $100 \mathrm{mg} \mathrm{KBr}$ to form a pellet. The typical absorption bands of apatite in the region $1100-$ $1000 \mathrm{~cm}^{-1}$ and those of calcium oxalate at $1320,920,780$ and $520 \mathrm{~cm}^{-1}$ were selected and their absorbances were measured on the infrared spectra of 64 samples recorded with $620 \mathrm{MX}$ and the infrared spectra of 51 samples recorded with IRA-2 (Fig. 1 and 2). Comparing the absorbances with the contents of weddellite, whewellite and apatite estimated by TG, an attempt was made to determine the percentage of these components by infrared analysis of calcium oxalate stones.

The results are as follows:

1) It was reported by Bellanato and associates 7 ) that there was a direct correlation between the ratio of the absorbance of the band at $780 \mathrm{~cm}^{-1}$ to that of the band at $520 \mathrm{~cm}^{-1}\left(\mathrm{D} 780 \mathrm{~cm}^{-1} / \mathrm{D} 520 \mathrm{~cm}^{-1}\right)$ and the ratio of the whewellite content to the total of weddellite and whewellite. However, it was shown in this study that the correlation coefficient between these ratios was $-0.54(\mathrm{p}<0.01)$ when D780 $\mathrm{cm}^{-1} / \mathrm{D} 520 \mathrm{~cm}^{-1}$ was determined on 51 infrared spectra recorded with IRA-2 (Fig. 4).

2) It was reported by Takasaki10) that there was a good correlation between the ratio of the absorbance of the bands in the region $1100-1000 \mathrm{~cm}^{-1}$ to that of the band at $1320 \mathrm{~cm}^{-1}$ (Dp/Do) and the ratio of the apatite content to the total of calcium oxalate and apatite. It was shown in this study that the correlation coefficient between $\mathrm{Dp} / \mathrm{Do}$ where the ratio of $\mathrm{Dp}$ to Do was less than 1.0 and the ratio of the apatite content to the total of calcium oxalate and apatite was $0.96(\mathrm{p}<0.01)$ when $\mathrm{Dp} / \mathrm{Do}$ was determined with $620 \mathrm{MX}$ in 52 samples and 0.95 ( $\mathrm{p}<0.01$ ) when determined with IRA-2 in 47 samples (Fig. 5).

3) The correlation coefficient between the absorbance of the band at $920 \mathrm{~cm}^{-1}\left(\mathrm{D} 920 \mathrm{~cm}^{-1}\right)$ and the weddellite content was $0.87(\mathrm{p}<0.01)$ when D920 $\mathrm{cm}^{-1}$ was measured with $620 \mathrm{MX}$ in 35 samples and 0.81 ( $\mathrm{p}<0.01$ ) when measured with IRA-2 in 29 samples (Fig. 8).

4) The correlation coefficient between $\mathrm{D} 780 \mathrm{~cm}^{-1}$ and the whewellite content was $0.89(\mathrm{p}<0.01)$ when $\mathrm{D} 780 \mathrm{~cm}^{-1}$ was measured with $620 \mathrm{MX}$ in 64 samples and $0.88(\mathrm{p}<0.01)$ when determined with IRA-2 in 51 samples (Fig. 9). The correlation coefficient between D520 $\mathrm{cm}^{-1}$ and the whewellite content was $0.92(\mathrm{p}<0.01)$ when D520 $\mathrm{cm}^{-1}$ was determined with IRA-2 in 51 samples (Fig. 10).

5) The correlation coefficient between the depth $(\mathrm{mm})$ of the band at $780 \mathrm{~cm}^{-1}$ and the whewellite content was $0.87(620 \mathrm{MX}, \mathrm{p}<0.01)$ and 0.89 (IRA-2, $\mathrm{p}<0.01)$, and that between the depth of the band at $520 \mathrm{~cm}^{-1}$ and the whewellite content was 0.92 (IRA-2, $\mathrm{p}<0.01$ ). Thus it was suggested that the depth of the absorption band was also correlated with the whewellite content in calcium oxalate stones (Fig. 11).

6) Each of the absorption bands in the region $3600-3000 \mathrm{~cm}^{-1}$, at $920 \mathrm{~cm}^{-1}$, at $780 \mathrm{~cm}^{-1}$ and at $670 \mathrm{~cm}^{-1}$ was classified into three patterns and scored according to the shape and depth; those characteristic of weddellite were given two points, those characteristic of whewellite were given 0 point and those showing the intermediate shape and depth were given one point (Fig. 3). The total point 
(Weddellite score) which ranges between 8 and 0 was then compared with the ratio of the weddellite content to the total of weddellite and whewellite (Fig. 12). Since the correlation coefficient between these parameters was $0.93(620 \mathrm{MX}, \mathrm{p}<0.01)$ and 0.95 (IRA-2, $\mathrm{p}<0.01)$, it is considered that the weddellite score is useful for the semi-quantitative determination of weddellite and whewellite in calcium oxalate stones.

要旨：蓚酸カルシウムと燐酸カルシウムから構成される上部尿路結石80個に対して, 2 種類の赤外分光 光度計（620MX, IRA-2）を用いて whewellite, weddellite, apatiteの定量を試みた.

1）Bellanato らが報告した吸光度比 $\mathrm{D} 780 \mathrm{~cm}^{-1} / \mathrm{D} 520 \mathrm{~cm}^{-1}$ (IRA-2）と，TGによって求めた蓚酸カル シウム 1 水化物含有比 whewellite/weddellite+whewellite には, $\mathrm{r}=-0.54$ の相関を認めた.

2）高崎が報告した吸光度比 $\mathrm{D} 1,100-1,000 \mathrm{~cm}^{-1} / \mathrm{D} 1,320 \mathrm{~cm}^{-1}$ (以下 $\mathrm{Dp} / \mathrm{Do}$ ) は，TGによって求めた apatite 含有率と $\mathrm{r}=0.96(620 \mathrm{MX}), \mathrm{r}=0.95$ (IRA-2) の相関を示した.

3）吸光度 D920 $\mathrm{cm}^{-1}$ は, TGにより求めた weddellite 含有率と $\mathrm{r}=0.87$ (620MX), $\mathrm{r}=0.81$ (IRA-2) の相関を示した。

4) 吸光度 D780 $\mathrm{cm}^{-1}$ は, TGにより求めた whewellite 含有率と $\mathrm{r}=0.89(620 \mathrm{MX}), \mathrm{r}=0.88$ (IRA-2) の相関を示し，吸光度 D520 $\mathrm{cm}^{-1}$ (IRA-2）は， whewellite 含有率と $\mathrm{r}=0.92$ の相関を示した.

5）各吸収帯の深さ（Fig. 1, Fig. 2の io,ip）は，TG で求めた whewellite, apatite 含有率とよく相関 した.

6） 3,600-3,000 $\mathrm{cm}^{-1}, 920 \mathrm{~cm}^{-1}, 780 \mathrm{~cm}^{-1}, 670 \mathrm{~cm}^{-1}$ の各吸収帯について，吸収帯の形状と深さから, 3 段階に分類した. whewellite に特徵的な形状を 0 点, weddellite に特徵的な形状を 2 点とし, それら の中間を 1 点とした。その合計点と, TGにより求めた蓚酸カルシウム 2 水化物含有比 weddellite/weddellite+whewellite とは, $\mathrm{r}=0.93$ (620MX), $\mathrm{r}=0.95$ (IRA-2) の相関を示した.

以上から, 蓚酸カルシウムと燐酸カルシゥムから構成される結石では, 赤外分光光度計の機種にかか わらず，赤外分光分析による weddellite $\left(\mathrm{D} 920 \mathrm{~cm}^{-1}\right)$, whewellite $\left(\mathrm{D} 780 \mathrm{~cm}^{-1}, \mathrm{D} 520 \mathrm{~cm}^{-1}\right)$, apatite (Dp) の定量が可能であることがわかった．また，吸光度の代わりに，吸収帯の深さを用いることも可能であ ると思われる。ささに, $3,600-3,000 \mathrm{~cm}^{-1}, 920 \mathrm{~cm}^{-1}, 780 \mathrm{~cm}^{-1}, 670 \mathrm{~cm}^{-1}$ の各吸収帯を, 点数化(weddellite score)すれば, 蓚酸カルシウム 2 水化物含有比が求められること, 高崎が報告した Dp/Do と apatite 含 有率には，直線的な相関関係があることから，結石試料を秤量しなくても，whewellite，weddellite， apatite の半定量が可能であると考兄れる.

\section{はじめに}

尿路結石の $70 \%$ 以上は，蓚酸カルシウムを主成分と する蓚酸カルシウム結石である1). 尿石では, 蓚酸カル シウムは，蓚酸カルシウム 1 水化物（whewellite）あ るいは苳酸カルシウム 2 水化物 (weddellite) として存 在している ${ }^{2) \sim 4}$. 両者は, 偏光顕微鏡的観察やX $\mathrm{X}$ 線分析 によって区別されるが，赤外分光分析による判別は困 難とされてきだ ${ }^{516)}$. しかし，小出ら ${ }^{3)}$ は, 赤外分光分析 によって,蓚酸カルシウム結石を whewellite を主体と する結石と weddellite を主体とする結石とに分類し， 後者は前者之較べて再発しやすいことを指摘してい る. 小出らは, Bellanato ら ${ }^{7)}$ の方法に準じ, 赤外分光 分析によって whewellite と weddellite を判別してい るが Bellanato らの方法に問題はないのであろうか.

熱重量測定 (以下，TG) によれば，蓚酸カルシウム
結石の whewellite, weddellite, apatite 含有率を知る ことができる ${ }^{8)}$.

著者は, TGによって, whewellite, weddellite, apatite 含有率が判明している結石試料を用い, TG に よる定量結果と比較することによって，赤外分光分析 による whewellite, weddellite, apatite の定量を試み たので，ここに報告する。

\section{材料と方法}

過去 5 年間に自然排出された上部尿路結石を使用し た. 結石は, 水洗した後, 室温にて乾燥させた。次に, めのう乳鉢で結石全体あるいは結石の半分を粉末と し，X線分析を施行した後, 試料びんに移し, 結石試 料とした. 結石試料は, 直射日光を避け, 室温で保管 した。

蓚酸カルシウムと燐酸カルシウムから構成された結 
石試料は, TGによって, whewellite, weddellite, apatite 含有率が判明している8).このうち, TG 後も結 石試料が $1 \mathrm{mg}$ 以上残っているものは80例で，これを赤 外分光分析に用いた。

赤外分光光度計には，日本分光製 IRA-2型（以下, IRA-2）と Beckman 社製620MX（以下 $620 \mathrm{MX}$ ）を使 用した。測定域は，IRA-2では $4,000 \mathrm{~cm}^{-1}-400 \mathrm{~cm}^{-1}$, $620 \mathrm{MX}$ では $4,000 \mathrm{~cm}^{-1}-600 \mathrm{~cm}^{-1}$ である。結石試料 $1.0 \mathrm{mg}$ と $\mathrm{KBr} \quad 100 \mathrm{mg}$ （IRA-2）または $\mathrm{KBr} \quad 150 \mathrm{mg}$ （620MX）をよく混和し， $\mathrm{KBr}$ 錠剤を作成した。半 の結石試料は $2 \mathrm{mg}$ 以下であったため, IRA-2 と620MX の両者にて赤外分光分析を施行できたのは，80例のう
ち35例のみであった，他の45例は，IRA-2あるいは620 $\mathrm{MX}$ のみで赤外分光分析を施行した。したがって IRA-2による分析例は51例, $620 \mathrm{MX}$ による分析例は64 例となった。

Fig. 1は, IRA-2での分析例である. 吸光度の測定は base line 法に従った ${ }^{10)}$. まず, 赤外線スペクトル上で, $\mathrm{KBr}$ のみの透過光の強さ $\mathrm{Ik}(\mathrm{mm})$ を測定する．次い で, $1,100-1,000 \mathrm{~cm}^{-1}$ の吸収帯の深さ ip (mm), 1,320 $\mathrm{cm}^{-1}, 920 \mathrm{~cm}^{-1}, 780 \mathrm{~cm}^{-1}, 520 \mathrm{~cm}^{-1}$ の吸収帯の深さ io (mm)を測定する。1,100-1,000 $\mathrm{cm}^{-1}$ に打ける吸収帯 の透過光の強さ $\mathrm{Ip}=\mathrm{Ik}-\mathrm{ip}$ と, $1,320 \mathrm{~cm}^{-1}, 920 \mathrm{~cm}^{-1}$, $780 \mathrm{~cm}^{-1}, 520 \mathrm{~cm}^{-1}$ の吸収帯の透過光の強さ $\mathrm{Io}=\mathrm{Ik}$ -

Fig. 1 Infrared spectrum of a renal stone recorded with 1RA-2. Dp (Do) $=\log$ $\mathrm{Ik}-\log \mathrm{Ip}(\mathrm{Io})=\mathrm{Ik}-\mathrm{ip}$ (io)

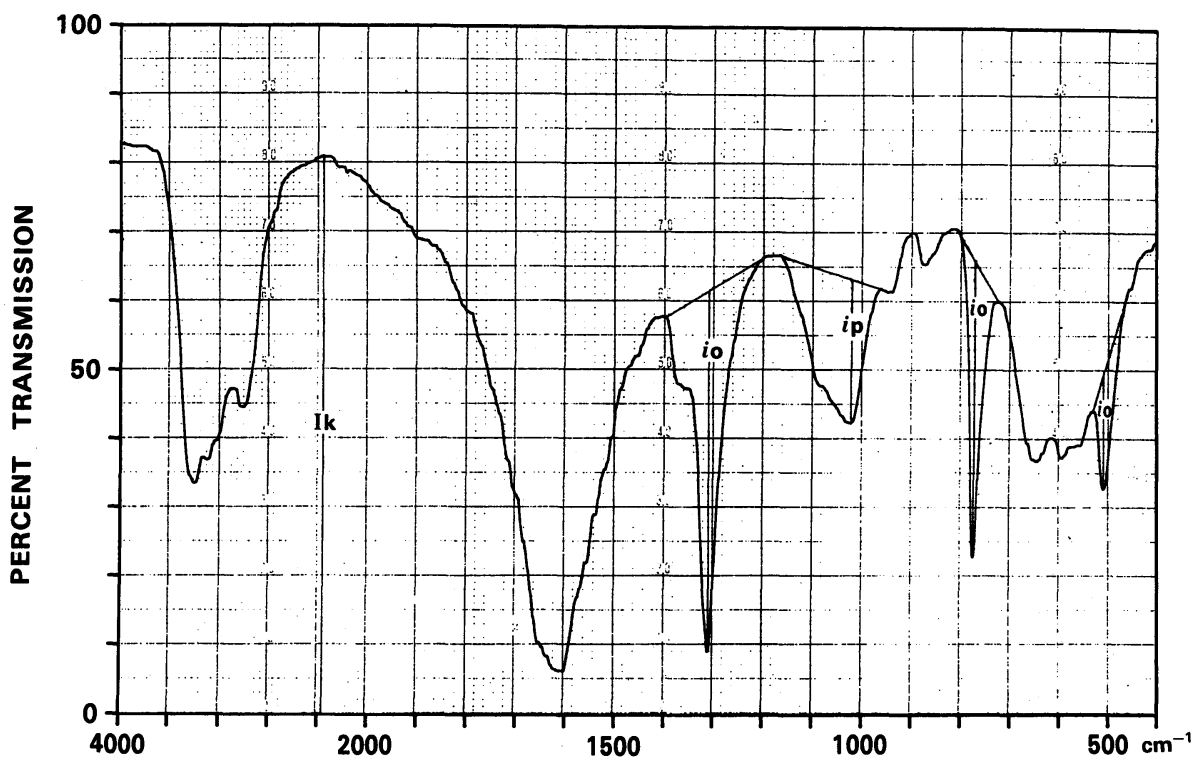

Fig. 2 Infrared spectrum of a renal stone recorded with $620 \mathrm{MX}$.

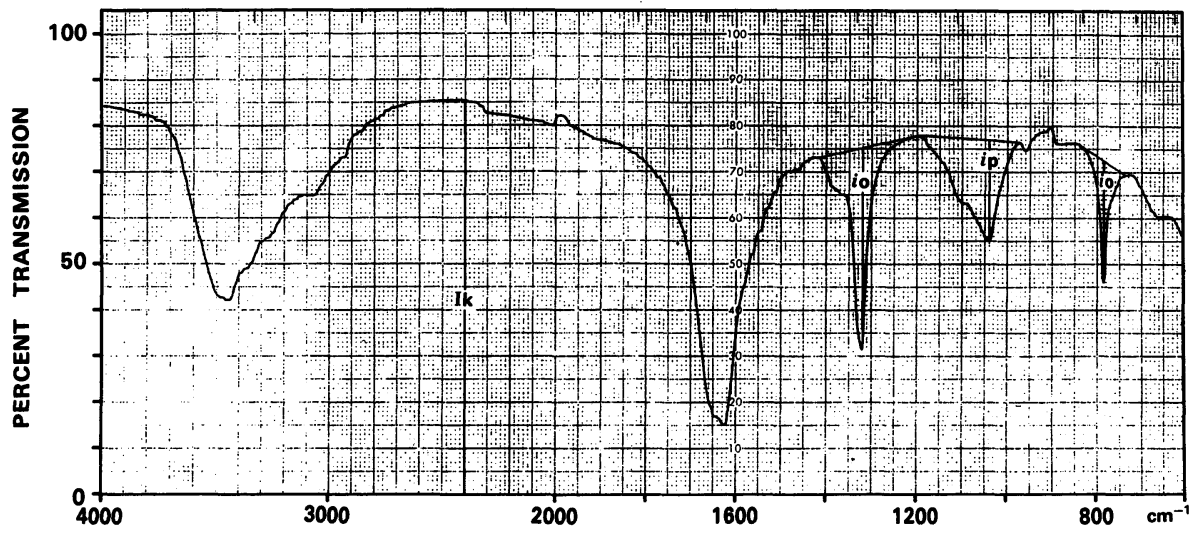


io を求め, それぞれの吸収帯の吸光度 $\mathrm{Dp}=\log \mathrm{Ik}$ 一 $\log \mathrm{Ip}, \mathrm{Do}=\log \mathrm{Ik}-\log$ Io 求めた.

Fig. 2は620MX での分析例である. IRA-2による分 析例之同様に，吸光度 $\mathrm{Dp}$, 吸光度 Doを求めた。この

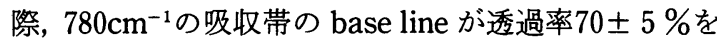
示すようにした。

赤外線スペクトル上, whewellite と weddellite に明 瞭な違いを認める吸収帯（I） $3,600-3,000 \mathrm{~cm}^{-1}$, (II) $920 \mathrm{~cm}^{-1}$ ，(III） $780 \mathrm{~cm}^{-1}$ ，(IV） $670 \mathrm{~cm}^{-1}$ を選び，（I） 〜 (IV)の各吸收帯の形状や深さから, whewellite に特 徵的なものを 0 点, weddellite に特徵的なものを 2 点, 中間型を 1 点とした. Fig. 3は，上段に weddellite 結 石,下段に whewellite 結石の赤外線スペクトルを示し た. $920 \mathrm{~cm}^{-1}$ の吸収帯については, 明瞭に認められるも のを 2 点, $670 \mathrm{~cm}^{-1}$ の吸収帯については明瞭に認めら れるものを 0 点とした。上段の吸収帯 (I), (II), (III), (IV) は各 2 点, 下段の吸収帯 (I), (II), (III), (IV) は各 0 点となる．各吸収帯での点数の合計を weddellite score とした. Fig. 3上段の weddellite score は 8 点，下段の weddellite scoreは 0 点である. Fig. 1, Fig. 2の weddellite scoreは，それぞれ 0 点，4点で ある。

\section{結 果}

Fig. 4 は, IRA-2によって求めた $780 \mathrm{~cm}^{-1}$ と $520 \mathrm{~cm}^{-1}$ の吸収帯の吸光度比 D $780 \mathrm{~cm}^{-1} / \mathrm{D} 520 \mathrm{~cm}^{-1}$ と, TG K よって求めた蓚酸カルシウム 1 水化物含有比 whewellite/weddellite+ whewelliteを比較したもの

Fig. 3 Infrared spectra of a weddellite stone (top) and a whewellite stone (bottom), showing the absorption bands (I, II, III and IV) characteristic of weddellite or whewellite.

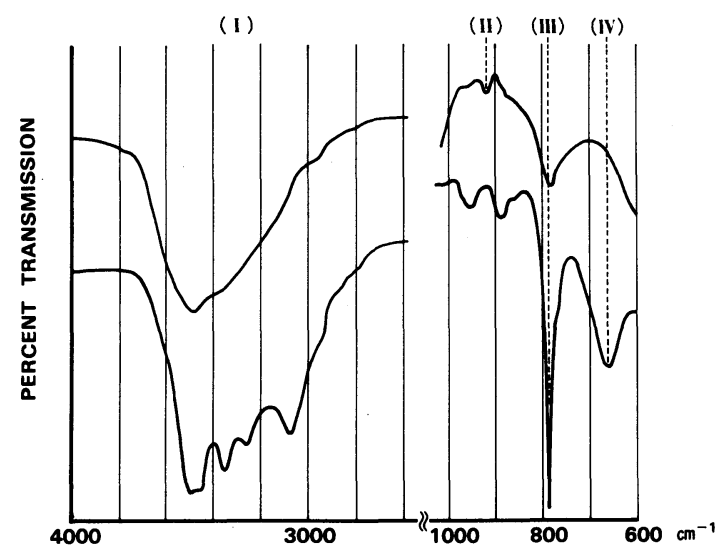

である. Bellanato ら゙)は，この両者に正の相関を認め ているが，本結果では $\mathrm{r}=-0.54(\mathrm{p}<0.01)$ と負の相 関を示した。

Fig. 5は, 620MXによって求めた $1,100-1,000$ $\mathrm{cm}^{-1}$ の吸収帯の吸光度 $\mathrm{Dp}$ と $1,320 \mathrm{~cm}^{-1}$ の吸収帯の吸 光度 Do との比 $\mathrm{Dp} / \mathrm{Do}$ と, TGによって得られた apatite 含有率を比較したものである. Dp/Doが 1 以 上の場合には, Do/Dp と, apatite 含有率を比較した。 高崎 $\left.{ }^{10}\right)$ は, この吸光度比 $\mathrm{Dp} / \mathrm{Do}(\mathrm{Dp} / \mathrm{Do}$ が 1 以上の場

Fig. 4 Correlation between $\mathrm{D} 780 \mathrm{~cm}^{-1} / \mathrm{D} 520 \mathrm{~cm}^{-1}$ ratio (IRA-2) and whewellite/weddellite + whewellite ratio (TG).

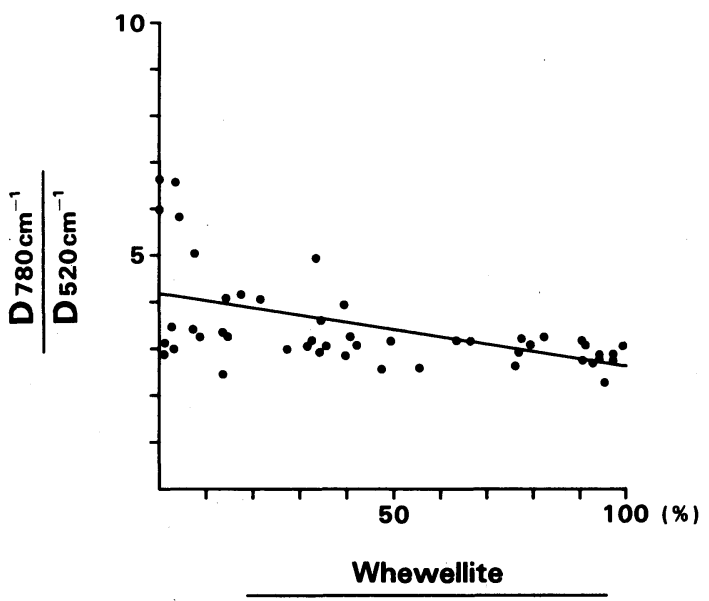

Fig. 5 Correlation between Dp/Do ratio (620MX) and apatite/weddellite + whewellite + apatite ratio (TG).

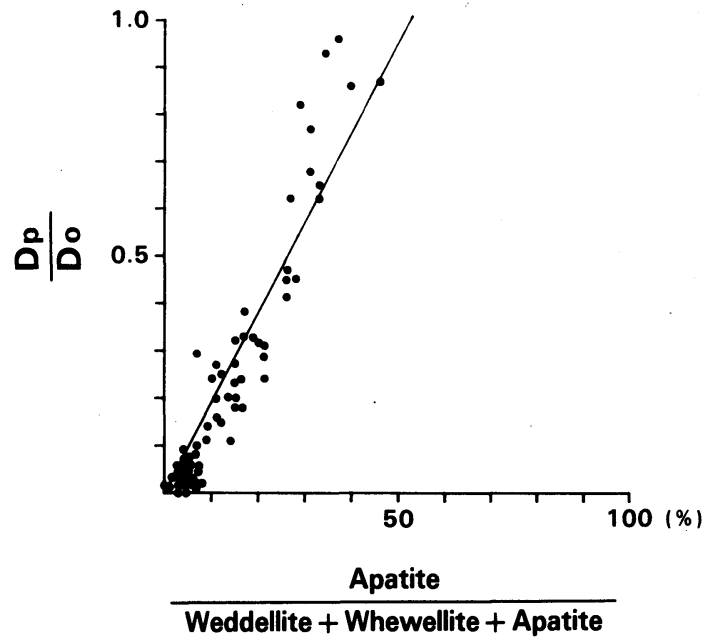


合には Do/Dp）と，化学的な定量分析から求められた apatite 含有率とから検量曲線を作成し, apatite の定 量を試みている。本結果では, 両者は直線的な相関を 有していた $(\mathrm{r}=0.96, \mathrm{p}<0.01)$ 。 なた，IRA-2によっ て求めた $\mathrm{Dp} / \mathrm{Do}$ と, TGによって得られた apatite 含 有率とを比較した場合でも， $\mathrm{r}=0.95(\mathrm{p}<0.01)$ の相 関を認めた。 Dp/Doが 1 以上の 16 例では, Do/Dp と apatite 含有率とは, $\mathrm{r}=-0.93(\mathrm{p}<0.01)$ の相関を示 した.

Fig. 6は, 620MX によって求めた $1,320 \mathrm{~cm}^{-1}$ の吸光

Fig. 6 Correlation between Do (620MX) and total content (wt\%) of weddellite and whewellite determined by $\mathrm{TG}$.

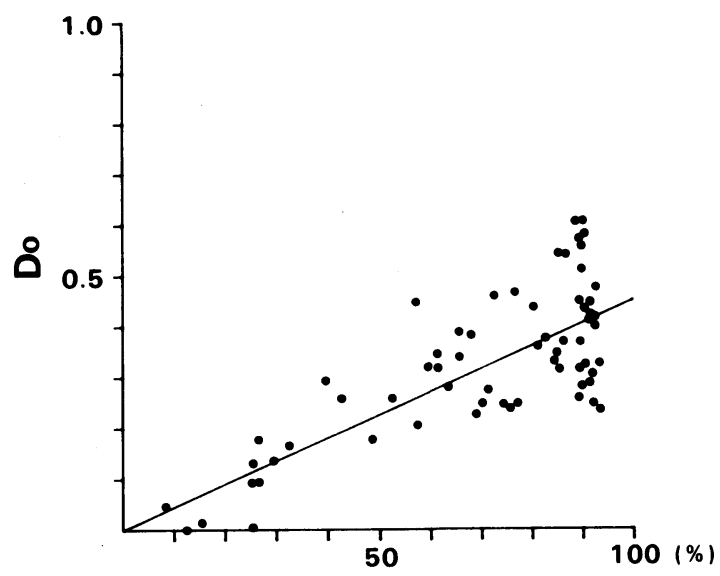

Weddellite + Whewellite

Fig. 7 Correlation between Dp (620MX) and apatite content (wt\%) determined by TG.

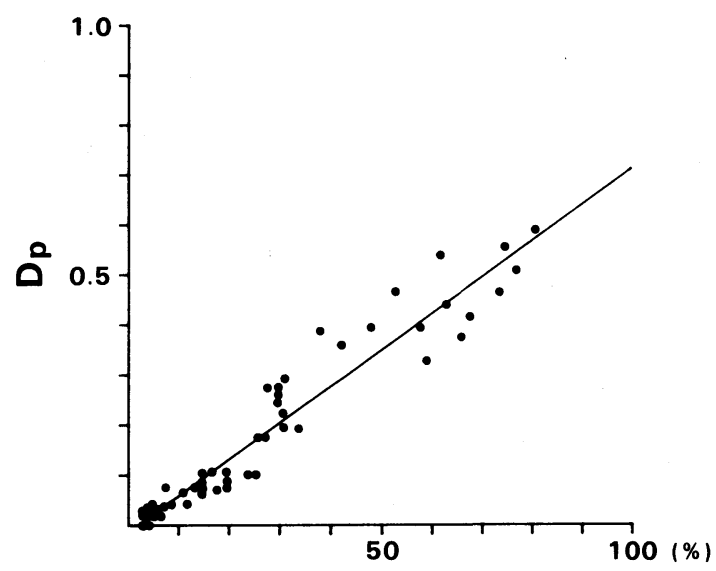

Apatite
度 Do と, TGによって求めた蓚酸カルシウム含有率 を比較したものである. 両者は $\mathrm{r}=0.76(\mathrm{p}<0.01)$ の 相関を示したが, IRA-2によって求めた $1,320 \mathrm{~cm}^{-1}$ の吸 光度 Do と, TGによって求めた蓚酸カルシウム含有 率を比較すると, $\mathrm{r}=0.38 （ \mathrm{p}<0.01 ）$ の相関を示すに すぎなかった。

Fig. 7は, 620MXによって求めた $1,100-1,000$ $\mathrm{cm}^{-1}$ の吸收帯の吸光度 $\mathrm{Dp}$ と, TGによって求めた apatite 含有率との相関を検討したものである.両者は $\mathrm{r}=0.97(\mathrm{p}<0.01)$ の相関を示した. IRA-2で求めた吸 光度 $\mathrm{Dp}$ と, TGによって求めた apatite 含有率とは, $\mathrm{r}=0.91(\mathrm{p}<0.01)$ の相関を示した. Hesse ら ${ }^{11)}$ は, 920 $\mathrm{cm}^{-1}$ の吸収帯は, weddellite で認められ, whewellite では認められないとしている。 Fig. 8は, 620MXに よって求めた $920 \mathrm{~cm}^{-1}$ の吸収帯の吸光度 $\mathrm{D} 920 \mathrm{~cm}^{-1}$ と, TGによって求めた weddellite 含有率を比較したも のである. 64 結石中, $920 \mathrm{~cm}^{-1}$ の吸収帯の吸光度が 0 の ものを除いた 35 結石について両者を比較すると， $\mathrm{r}=$ $0.87(\mathrm{p}<0.01)$ の相関が認められた. IRA-2でも， 29 例について同様の比較を行なったが, $\mathrm{r}=0.81(\mathrm{p}<$ 0.01）の相関が認められた.

$780 \mathrm{~cm}^{-1}$ の吸収帯は, weddellite 及び whewellite の いずれにも認められる11)が, 吸収帯の深さと形状に差 異がある．Fig. 9は，620MXによって求めた $780 \mathrm{~cm}^{-1}$ の吸収帯の吸光度 $\mathrm{D} 780 \mathrm{~cm}^{-1}$ と, TGによって求めた whewellite 含有率とを比較したものである. 両者の間 には, $\mathrm{r}=0.89(\mathrm{p}<0.01)$ の相関を認めた。同様に, IRA-2によって求めた $780 \mathrm{~cm}^{-1}$ の吸収帯の吸光度 D780 $\mathrm{cm}^{-1}$ は, TGによって求めた whewellite 含有率と, $\mathrm{r}=$ $0.88(\mathrm{p}<0.01)$ の相関を示した.

$520 \mathrm{~cm}^{-1}$ における吸收帯は, $780 \mathrm{~cm}^{-1}$ における吸收帯 と同じく, weddellite と whewellite とで共に認められ

Fig. 8 Correlation between $\mathrm{D} 920 \mathrm{~cm}^{-1}$ (620MX) and weddellite content (wt\%) determined by TG.

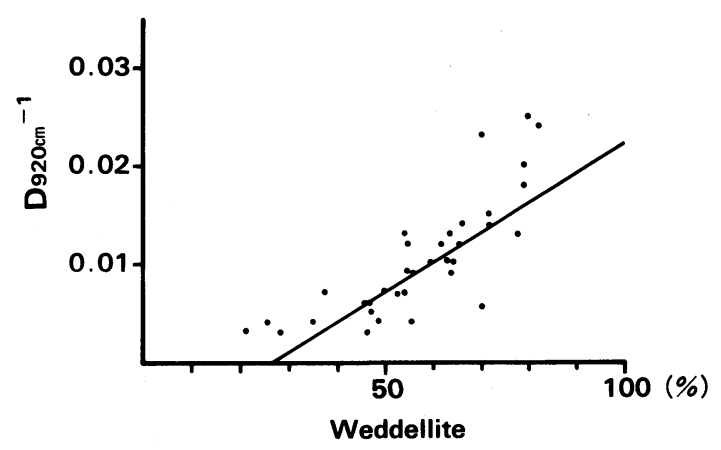


Fig. 9 Correlation between $\mathrm{D} 780 \mathrm{~cm}^{-1}(620 \mathrm{MX})$ and whewellite content (wt\%) determined by TG.

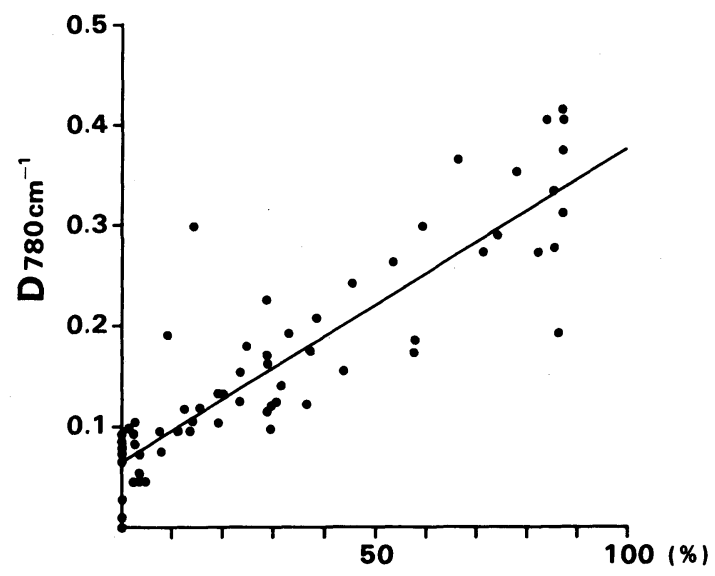

Whewellite

Fig. 10 Correlation between D520 $\mathrm{cm}^{-1}$ (IRA-2) and whewellite content (wt\%) determined by TG.

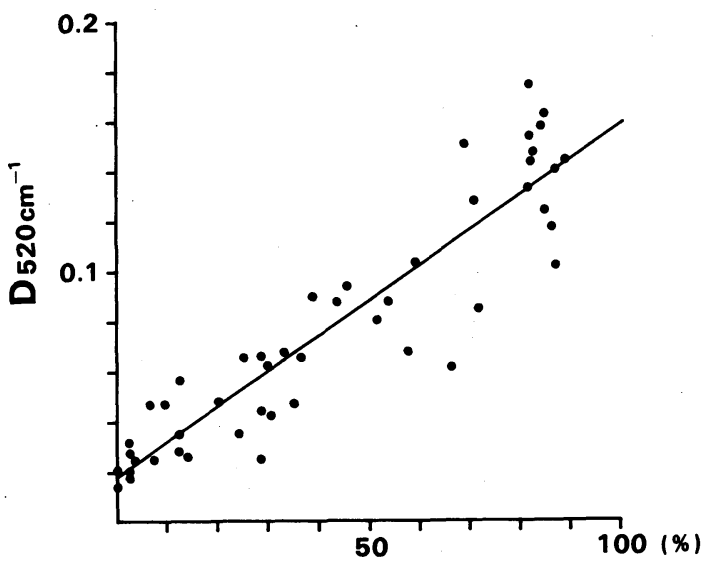

Whewellite

る11)が, 吸収帯の深さ形状に差異がある.620MX では, 測定域が $600 \mathrm{~cm}^{-1}$ までであるため, $520 \mathrm{~cm}^{-1}$ の吸収帯の 観察はできない. Fig. 10は, IRA-2によって求めた520 $\mathrm{cm}^{-1}$ での吸収帯の吸光度 $\mathrm{D} 520 \mathrm{~cm}^{-1}$ と, TGによって 求めた whewellite 含有率を比較したものである.両者 は $\mathrm{r}=0.92(\mathrm{p}<0.01)$ の相関を示した.

さて, 吸光度の測定方法から, 吸収帯の深さは, 吸 光度に代わって含有率の測定に有用であろうと考兄 た. Fig. 11は, $620 \mathrm{MX}$ によって求めた $780 \mathrm{~cm}^{-1}$ の吸収
帯の深さ io (mm) と, TGによって求めた whewellite 含有率を比較検討したものである. 両者は, $\mathrm{r}=0.87$ $(\mathrm{p}<0.01)$ の相関を示した. IRA-2で同様の比較をする と, $\mathrm{r}=0.89(\mathrm{p}<0.01)$ の相関が認められた. $1,320 \mathrm{~cm}^{-1}$ の吸収帯の深さは，TG で求めた蓚酸カルシウム含有 率と620MX で $\mathrm{r}=0.83(\mathrm{p}<0.01)$, IRA-2で $\mathrm{r}=0.32$ $(\mathrm{p}<0.05)$ の相関を示し, $520 \mathrm{~cm}^{-1}$ の吸收帯の深さ (IRA-2) は, TGで求めた whewellite 含有率と $\mathrm{r}=$ $0.92(\mathrm{p}<0.01)$ の相関を示した。 また， $1,100-1,000$

Fig. 11 Correlation between depth $(\mathrm{mm})$ of the absorption band at $780 \mathrm{~cm}^{-1}(620 \mathrm{MX})$ and whewellite content ( $w \mathrm{t} \%$ ) determined by TG.

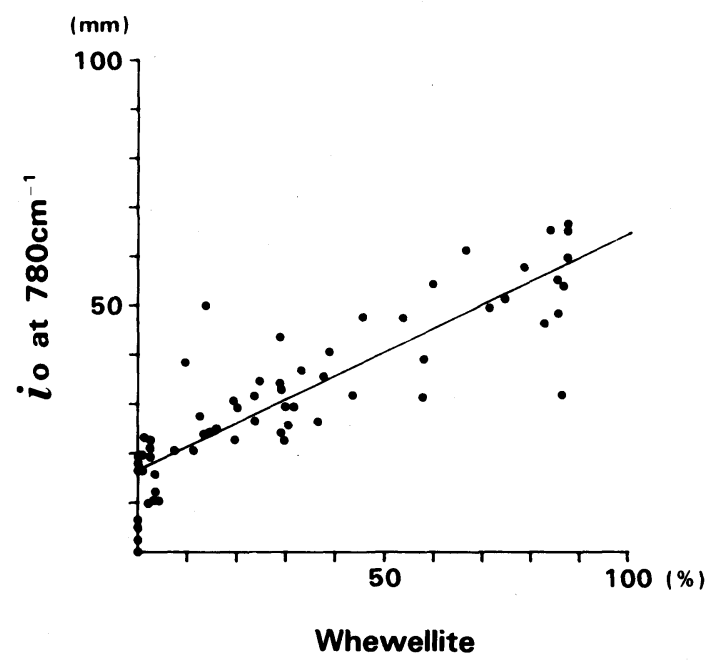

Fig. 12 Correlation between weddellite score $(620$ MX) and weddellite/weddellite + whewellite ratio (TG).

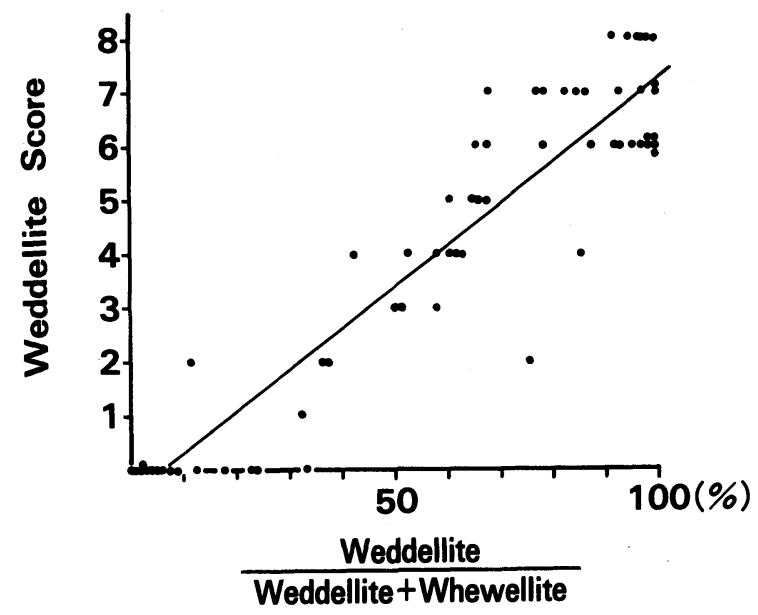


$\mathrm{cm}^{-1}$ の吸收帯の深さは, TG で求めた apatite 含有率 と, 620MX で $\mathrm{r}=0.96(\mathrm{p}<0.01)$, IRA-2で $\mathrm{r}=0.93$ $(\mathrm{p}<0.01)$ の相関を示した.

Fig. 12は, 点数表示により, weddellite の半定量を 試みた結果である. $620 \mathrm{MX}$ で求めた weddellite score と, TG で求めた蓚酸カルシウム 2 水化物含有比 wed-

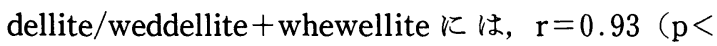
$0.01)$ の相関を認めた。 IRA-2では，両者に $\mathrm{r}=0.95$ $(\mathrm{p}<0.01)$ の相関を認めた。

\section{考 察}

蓚酸カルシウム結石は, 蓚酸カルシウム 1 水化物を 主体とする whewellite 結石と, 蓚酸カルシウム 2 水化 物を主体とする weddellite 結石に分類される2 1963年, Prien ${ }^{21}$ は, 蓚酸カルシウム結石を ureteral type と general type に分類し, 後者は前者よりも大き く,外科的手術の対象となることが多いと述べている.

Prien は, ureteral type, general type ともに, whewelliteから構成されるとしているが, general type の苳 酸カルシウム結石は, weddellite 結石を示唆する構造 を有していることは興味深い. 最近, 小出ら ${ }^{3)}$ は, weddellite 結石が, whewellite 結石よりも再発しやすいこ とを指摘しているが, 戸塚ら ${ }^{488} も$, weddellite 結石が whewellite 結石よりも有意に大きいことを報告して いる.したがって, 蓚酸カルシウム結石を, whewellite 結石または weddellite 結石に分類することは，臨床的 に意義があるであろう。

whewellite, weddellite の定量には, X線分析预よび 熱分析が優れた方法であるが，X線回折装置，熱分析 装置はともに高価であり，我国ではあまり普及してい ない. 赤外分光分析法は, 微量の試料でも分析可能な こと，短時間で結果を得ることができることから，尿 路結石の分析法としては, 我国では最も広く普及して いる. したがって, 赤外分光分析法によって, whewellite, weddellite の定量が可能となれば, 蓚酸カルシウ ム結石の再発率を予測する上で有力な方法となるであ ろう.

高崎6) な関係を示唆しているが，赤外分光分析法による whewellite と weddellite $の$ 定量は困難であるとして いる.

Hesse $ら^{11}$ は, whewellite と weddellite の赤外線ス ペクトル上の吸収帯の差異について検討を行っている が，定量的応用には至っていない。

Bellanato ら ${ }^{7)}$ は, 純粋な whewellite (化学試薬) と weddellite (weddellite 結石) を種々の割合で混合し， 赤外分光分析を施行した．その結果, 吸光度比 D780 $\mathrm{cm}^{-1} / \mathrm{D} 520 \mathrm{~cm}^{-1}$ が, 蓚酸カルシゥム 1 水化物含有比 whewellite/weddellite + whewellite と正の相関を有 するとし，この吸光度比が, whewellite, weddellite の 定量に有用と報告した。 しかし, 著者の検討では, 両 者には, $\mathrm{r}=-0.54$ の相関が認められるにすぎなかっ た. $780 \mathrm{~cm}^{-1}$ と $520 \mathrm{~cm}^{-1}$ に扔ける吸光度は, whewellite 含有率の増加とともに増大する傾向にある。したがっ $\tau$, 吸光度比 $\mathrm{D} 780 \mathrm{~cm}^{-1} / \mathrm{D} 520 \mathrm{~cm}^{-1}$ と蓚酸カルシウム 1 水化物含有比とが正の相関を示さないことは容易に 想像できる。

高崎 ${ }^{10)}$ は, $1,050 \mathrm{~cm}^{-1}$ 付近の燐酸カルシウム (apatite) の吸収帯の吸光度 Dp r $1,320 \mathrm{~cm}^{-1}$ の蓚酸力 ルシウムの吸収帯の吸光度 Do との比 Dp/Do と, 化学 分析によって得られた燐酸カルシウム含有率 (apatite 含有率）とから検量曲線を作成し，この検量曲線によ り燐酸カルシウム含有率の定量が可能であるとした。

著者は, 吸光度比 $\mathrm{Dp} / \mathrm{Do}$ と apatite 含有率とには, 直線的な相関があることを示した。 このことは, $\mathrm{KBr}$ 錠剂の作成の際, 結石試料 $1.0 \mathrm{mg}$ を科量しなくても, 容易に燐酸カルシウム含有率および蓚酸カルシウム含 有率が求められることを示している.

$1,320 \mathrm{~cm}^{-1}$ の吸収帯は, 高崎 ${ }^{10)}$ が, Dp/Do を算出す る際に, 蓚酸カルシウムの吸収帯として使用している。 この吸収帯の吸光度は, 苳酸カルシウム含有率と高い 相関を有することが予想されたが，著者の検討では， あまり良い相関が得られなかった。しかし， $1,100-1,000 \mathrm{~cm}^{-1}$ の吸收帯の吸光度は, apatite 含有 率ときわめて高い相関を有することを認めた。

高崎6), Hesse ら ${ }^{11)}$ は, $920 \mathrm{~cm}^{-1}$ の吸収帯は weddellite に特徵的であるとしているが，著者は，この920 $\mathrm{cm}^{-1}$ の吸収帯の吸光度が, weddellite 含有率と $\mathrm{r}=$ $0.87(620 \mathrm{MX}), \mathrm{r}=0.81$ (IRA-2) の相関を示すことか ら, weddellite の定量に最も適していると考えている. しかし, weddellite 含有率が20３0\%以上にならない と, $920 \mathrm{~cm}^{-1}$ の吸収帯は観察できない欠点がある.

$780 \mathrm{~cm}^{-1}$ と $520 \mathrm{~cm}^{-1}$ の吸收帯は, whewellite, weddellite の双方にみられる ${ }^{11}$ が，吸収帯の形状にはかな りの差のあることがわかる. D780 $\mathrm{cm}^{-1}$ と whewellite 含有率には $\mathrm{r}=0.89(620 \mathrm{MX}), \mathrm{r}=0.88$ (IRA-2) の相 関があり, D520 $\mathrm{cm}^{-1}$ (IRA-2) と whewellite 含有率に は $\mathrm{r}=0.92$ の相関があることから, $780 \mathrm{~cm}^{-1}, 520 \mathrm{~cm}^{-1}$ の吸収帯の吸光度は, whewellite の定量に有用と考兄 
られる。

以上のように, 結石試料 $1.0 \mathrm{mg}$ を秤量すれば, 1,320 $\mathrm{cm}^{-1}, 1,100-1,000 \mathrm{~cm}^{-1}, 920 \mathrm{~cm}^{-1}, 780 \mathrm{~cm}^{-1}, 520 \mathrm{~cm}^{-1}$ の吸収帯の吸光度から, whewellite, weddellite, apatite の定量が可能となるであろう.

戸塚ら ${ }^{12)}$ は，赤外線スペクトル上で， $1,100-1,000$ $\mathrm{cm}^{-1}$ の吸収帯の面積を測定し, apatite の定量を試み ている. 著者は, 吸収帯の深さを測定し，TG で求めた whewellite, apatite 含有率と比較してみた。その結果, 深さも吸光度と同様に, whewellite, apatite 含有率と よく相関することがわかった，吸光度測定は，多少煩 雑といらこともあり, 吸収帯の深さは吸光度に代わっ て臨床応用できるであろう。さらに著者は， $3,600-3,000 \mathrm{~cm}^{-1}, 920 \mathrm{~cm}^{-1}, 780 \mathrm{~cm}^{-1}, 670 \mathrm{~cm}^{-1}$ の各吸 収帯を点数表示すれば, weddellite の半定量が可能で あることを述べた。この方法では，結石試料 $1.0 \mathrm{mg} の$ 秤量は必要ないと考党られるので, 同時に吸光度比 $\mathrm{Dp} / \mathrm{Do}$ を測定すれば，赤外分光分析に際し，結石試料 を秤量しなくても， apatite， weddellite拉よび whewellite 含有率を知ることができるであろう。

以上, 赤外分光分析では, 結石試料 $1.0 \mathrm{mg}$ を秤量す ることが望ましいが，結石試料を科量しなくても，苳 酸カルシウム結石における weddellite, whewellite の 半定量が可能であることを報告した。

稿を終えるにあたり，終始深甚なる御指導，御校閲を賜 わった自治医科大学泌尿器科教授米瀬泰行先生, 獨協医科 大学泌尿器科教授高崎悦司先生, 実験に際し御指導, 御協力 いただいた自治医科大学泌尿器科戸塚一彦先生に束心より 感謝の意を表します。

\section{文献}

1) Takasaki, E. : An observation on the composition and recurrence of urinary calculi. Urol. Int., 30, 228-236, 1975.

2) Prien, E.L.: Crystallographic analysis of urinary calculi: A 23-year survey study. J. Urol., 89, 917-924, 1963.

3) Koide, T., Itatani, H., Yoshioka, T., Ito, H.,
Namiki, M., Nakano, E., Okuyama, A., Takemoto, M. and Sonoda, T.: Clinical manifestations of calcium oxalate monohydrate and dihydrate urolithiasis. J. Urol., 127, 1067-1069, 1982.

4) Tozuka, K., Konjiki, T. and Sudo, T.: Study of passed stones by means of X-rays. infrared and thermal analyses. J. Urol., 130, 1119-1122, 1983.

5）市川篤二, 柿崎 勉, 今村一男, 高崎悦司, 千原吳 郎：尿石の赤外線スペクトルによる分析. 第 1 編, 定性的応用. 日泌尿会誌，50，1-21，1959.

6) Takasaki, E.: Personal Communication.

7) Bellanato, J., Delatte, C.L., Hidalgo, A. and Santos, M.: Application of infrared spectroscopy to the study of renal stones. In : Urinary Calculi. Recent Advances in Aetiology, Stone Structure and Treatment. proceedings of the International Symposium on Renal Stone Research. Madria, Spain, September 1972. Edited by L. Fifuentes Delate, A Rapado and A. Hodgkinson. pp. 237-246, Basel: S. Karger, 1973.

8）戸塚一彦, 大場修司, 徳江童彦, 米瀬泰行, 近喰利 光：自然排出された上部尿路結石の熱分析. 日泌 尿会誌，76，348-353， 1985.

9）戸塚一彦, 西村泰司, 秋元成太, 近喰利光, 小川秀 弥：自然排出された上部尿路結石108個の X 線分 析. 日泌尿会誌, 74, 357-359, 1983.

10）高崎悦司：尿石の赤外線スペクトルによる分析. 第 2 編，定量的応用．日泌尿会誌，51，639--663， 1960.

11) Hesse, A., Schneider, H.J., Schilling, I., Schrumpf, G. und Hienzsch, E.: Infrarotspektroskopische und Röntgenfeinstrukutruntersuchungen an Kalziumozalat-Harnsteinen. Schr. Inn. Med., 27, 560-565, 1972.

12）戸塚一彦, 阿部裕行, 箕輪龍雄, 近喰利光, 須藤俊 男：自然排出された“純粋な蓚酸カルシウム結石” の検討。日泌尿会誌，73，740-744，1982. （1986年 3 月 13 日受付） 